
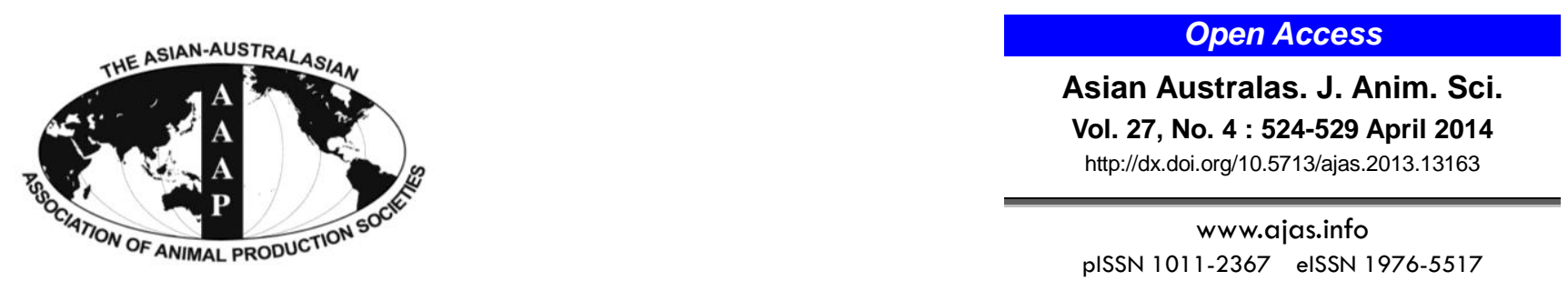

\title{
Determination of Tropical Forage Preferences Using Two Offering Methods in Rabbits
}

\author{
A. M. Safwat ${ }^{1,2, *}$, L. Sarmiento-Franco ${ }^{1}$, R. H. Santos-Ricalde ${ }^{1}$, and D. Nieves ${ }^{3}$ \\ ${ }^{1}$ Department of Animal Nutrition, Faculty of Veterinary Medicine and Animal Science, \\ University of Yucatan (UADY), Km 15.5 Carretera Mérida-Xmatkuil, Mérida, Yucatán, Mexico
}

\begin{abstract}
Two methods of feed preference trials were compared to evaluate the acceptability of 5 fresh foliages: Leucaena leucocephala, Moringa oleifera, Portulaca oleracea, Guazuma ulmifolia, and Brosimum alicastrum that was included as control. The evaluation included chemical analyses and forage intake by rabbits. The first method was a cafeteria trial; 12 California growing rabbits aged $8 \mathrm{wk}$, allocated in individual cages, were offered the five forage plants at the same time inside the cage, while in the second trial 60 California growing rabbits aged $8 \mathrm{wk}$, allocated individually, were randomly distributed into 5 experimental groups ( $\mathrm{n}=12 /$ group); for each group just one forage species was offered at a time. The testing period for each method lasted for $7 \mathrm{~d}$, preceded by one week of adaptation. The results showed that B. alicastrum and L. lecocephala were the most preferred forages while on the contrary G. ulmifolia was the least preferred one by rabbits. The results also revealed that the CV\% value for the 2nd method (16.32\%), which the tested forages were presented separately to rabbits, was lower and methodologically more acceptable than such value for the $1^{\text {st }}$ st method $(34.28 \%)$, which all forages were presented together at the same time. It can be concluded that a range of tropical forages were consumed in acceptable quantities by rabbits, suggesting that diets based on such forages with a concentrate supplement could be used successfully for rabbit production. However, growth performance studies are still needed before recommendations could be made on appropriate ration formulations for commercial use. (Key Words: Feed Preference, Cafeteria Trial, Tropical Forages, Rabbits)
\end{abstract}

\section{INTRODUCTION}

Modern animal production faces conflicting demands to produce large volumes of high-quality food at low prices. Nutritional solutions have now become even more important to resolve these demands and this can be achieved by taking full advantage of the alternative feed resources, such as tropical plants, in rabbit diets. Furthermore one of the ways of reducing the cost of animal production in developing countries and therefore making protein available to people at cheaper prices is by the use of

\footnotetext{
* Corresponding Author: A. M. Safwat. Tel: +52-1-9992150994, Fax: +52-9999423200, E-mail: assemsafwat2004@yahoo.com ${ }^{2}$ Department of Poultry Production, Faculty of Agriculture (ElShatby), Alexandria University, Alexandria, Egypt.

${ }^{3}$ National University of Llanos "Ezequiel Zamora" (UNELLEZ), Guanare, Portuguesa, Venezuela.

Submitted Mar. 20, 2013; Accepted Oct. 22, 2013; Revised Jan. 7, 2014
}

agricultural by-products and tropical plants which are not directly used by humans as food to feed livestock (Asar et al., 2010).

Rabbits can convert locally available plant products such as Leuceana leucocephala (Raharjo and Cheeke, 1985) and by-product feeds (Raharjo et al., 1986) into animal protein for human consumption. FAO (1997) reports emphasized that the high rate of growth in meat consumption can be met through the increase in production of short cycle animals, such as rabbits, kept by the small scale farmers.

Rabbits are very selective in their feeding behavior and in the wild will nibble and select specific plant parts. They generally select leaves rather than stems, young plant materials rather than old and green rather than dry materials, resulting in a diet that is higher in protein and digestible energy and lower in fiber than the available total plant material. They are much more sensitive to slight changes in the feed than other livestock. Sometimes they will refuse to

Copyright $@ 2014$ by Asian-Australasian Journal of Animal Sciences This is an open-access article distributed under the terms of the Creative Commons Attribution Non-Commercial License (http://creativecommons.org/licenses/by-nc/3.0/), which permits unrestricted non-commercial use, distribution, and reproduction in any medium, provided the original work is properly cited. 
accept a new diet and will starve for several days rather than even taste the new feed (McNitt et al., 1996). When an unusual diet was presented to rabbits, it was clearly rejected in a free-choice test, but it was consumed in a long-term single food test (De Blas and Wiseman, 2010).

Investigating the possible utilization of variety of forages as feedstuffs in rabbit diets is common and of particular importance in tropical countries. Little work has been conducted to evaluate the nutritive value of such plants, and most attempts have been focused on single or double forage evaluation.

This experiment consisted of comparing two different methods of cafeteria trial which were conducted to measure feed preferences of rabbits when they were fed different fresh forages either in a separate form or given them together.

\section{MATERIALS AND METHODS}

\section{Study site}

The study consisted of two trials which were carried out at the rabbit facility of the Faculty of Veterinary Medicine and Animal Science (FMVZ), University of Yucatan (UADY), Merida, Yucatan, Mexico. The climate is subhumid, with an average annual rainfall (highly variable) of $960 \mathrm{~mm}$, and 6 to 7 months of dry period; the annual average temperature is $26^{\circ} \mathrm{C}$. The daily average temperature is $23^{\circ} \mathrm{C}\left(\max 32^{\circ} \mathrm{C}, \min 15^{\circ} \mathrm{C}\right)$; while from March to September it is $30^{\circ} \mathrm{C}\left(\max 37^{\circ} \mathrm{C}, \min 23^{\circ} \mathrm{C}\right)$ as reported by Abou-Elezz et al. (2011).

\section{Animals and housing}

In the first trial, 12 unsexed growing California rabbits ( $8 \mathrm{wk}$ of age and $1,036 \pm 30 \mathrm{~g}$ initial live weight on average) were allocated in individual cages $(40 \times 60 \times 50 \mathrm{~cm})$. By the same way, 60 unsexed growing California rabbits, aged 8 wk and weighted on average $1,079 \pm 50 \mathrm{~g}$ were used in the second trial and were randomly divided into 5 groups each of 12 rabbits which were allocated in individual smaller cages $(40 \times 40 \times 50 \mathrm{~cm})$ as just one forage was presented to the rabbits.

\section{Forage plants}

Five tropical forages were used in this experiment, the forage species were Leucaena leucocephala, Moringa oleifera, Portulaca oleracea, Guazuma ulmifolia and Brosimum alicastrum, this last one was included as control forage, due to previous feeding experience and chemical composition of this plant. Whole plants (stems and leaves) of $P$. oleracea were harvested at 16-true leaf stage, while fresh leaves of the other forages were harvested from trees (2 to 4-year-old, last harvest was 4 months before) growing at the FMVZ farm. The forages were fed fresh to the rabbits.
The chemical analysis of the forages is shown in Table 2. Subsamples of each batch of forage material were taken, and oven-dried at $60^{\circ} \mathrm{C}$ until constant weight was attained to determine their dry matter contents.

\section{The first trial}

The first trial lasted for $14 \mathrm{~d} ; 7 \mathrm{~d}$ as an adaptation period and $7 \mathrm{~d}$ as a testing period (Somers et al., 2008). All the animals were fed on a commercial diet (the chemical composition of the commercial diet is presented in Table 1). Feed was restricted by $40 \mathrm{~g}$ concentrated feed, as digestible energy maintenance requirement, to force the rabbits to consume the rationed quantity of the forage feed and they were given free access to 5 species of green forage that were presented as a suspended band of every forage at the same time inside the cage two times a day (08:00 and 16:00 h). The locations of forages inside the cage were distributed in the same proportion. Initially $50 \mathrm{~g}$ of each species of forage was offered daily, and the feeding level of individual forage was increased by $10 \mathrm{~g}$, when more than $85 \%$ of the forage consumed. Daily feed intake (feed added - refused) and forage dry matter intake (DM added - DM refused) were determined.

\section{The second trial}

The second trial was also carried out for $14 \mathrm{~d}(7 \mathrm{~d}$ as an adaptation period and $7 \mathrm{~d}$ as a testing period). Rabbits were randomly divided into 5 equal groups; each group was included just one species of the forages as a suspended band inside the cage. Animals were fed on restricted commercial diet (40 g) and fresh forage was presented ad libitum two times a day. The DMI was determined and refusals were recorded daily.

\section{Chemical composition}

Proximate analysis of forage samples were carried out to determine the $\mathrm{DM}, \mathrm{CP}$, crude fiber $(\mathrm{CF})$, ether extract (EE) and ash content according to AOAC (1995). NDF and

Table 1. Chemical composition of the concentrated commercial diet (\% on DM basis)

\begin{tabular}{lc}
\hline Measurement & Concentrated diet \\
\hline $\mathrm{DM}(\%$ as fed $)$ & 88.5 \\
$\mathrm{CP}$ & 17.0 \\
Crude fiber & 14.4 \\
Ether extract & 2.2 \\
Ash & 7.5 \\
Calcium & 1.06 \\
Available phosphorus & 0.63 \\
Methionine & 0.42 \\
Lysine & 0.9 \\
DE $(\mathrm{kcal} / \mathrm{kg})$ & 2,580 \\
DE:CP & 151.76 \\
\hline
\end{tabular}


Table 2. Chemical composition of the studied forages (DM basis)

\begin{tabular}{lcccccccc}
\hline \multirow{2}{*}{ Forage } & DM & \multicolumn{7}{c}{ As g/100 g DM } \\
\cline { 3 - 9 } & (\% as fed $)$ & CP & CF & NDF & ADF & EE & Ash & Condensed tannin \\
\hline B. alicastrum & 42.50 & 14.07 & 14.65 & 36.00 & 28.80 & 3.24 & 11.75 & 0.96 \\
L. lecocephala & 37.23 & 20.26 & 16.31 & 34.24 & 25.90 & 4.61 & 7.96 & 2.74 \\
M. oleifera & 23.94 & 21.04 & 15.28 & 31.32 & 26.88 & 6.25 & 8.89 & 3.09 \\
P. oleracea & 12.72 & 17.28 & 13.54 & 35.84 & 20.17 & 2.00 & 25.67 & 0.15 \\
G. ulmifolia & 32.44 & 17.70 & 14.48 & 37.61 & 22.72 & 2.21 & 10.03 & 6.50 \\
\hline
\end{tabular}

$\mathrm{CF}=$ Crude fibre. $\mathrm{EE}=$ Ether extract.

ADF were determined following the method of Van Soest et al. (1991). Tannin content was determined according to Makkar et al. (1995).

\section{Statistical analysis}

A completely randomized design was used. Data were analyzed using ANOVA, with PROC MIXED of SAS 9.2 Software (SAS Institute, Cary, North Carolina, USA). The application of the least significant ranges among different treatment means was done according to Duncan (1955). Treatment effects were considered significant at $\mathrm{p} \leq 0.05$.

\section{RESULTS}

Chemical analysis on a DM basis of forages is listed in Table 2. The highest protein content was observed with $M$. oleifera and L. lecocephala, while B. alicastrum has the lowest value; however that value provides the appropriate level to meet protein requirements for growing rabbits. Crude fiber content was also the highest for L. lecocephala and $M$. oleifera but it was the lowest in $P$. oleracea, although it is worthy to note that values of the fiber fractions (CF, NDF, ADF) for the studied forages are kept in limited range, which reduces possibility of causing differences in preference or acceptability due to the dietary fiber. In regard to condensed tannin content of the tested forages, it is clear that P. oleracea and B. alicastrum have the lowest condensed tannin content followed by $L$. lecocephala and M. oleifera while G. ulmifolia has the highest value.

\section{First trial}

Values regarding daily DMI of the different forages that offered at the same time are presented in Table 3. The data revealed that L. leucocephala was significantly $(\mathrm{p}=0.001)$ the highest forage consumed $(25.66 \%$ of the total feed intake which consisted of forage and concentrated feed) followed by such B. alicastrum, $P$. oleracea, and $M$. oleifera $(7.91 \%, 7.26 \%$, and $6.83 \%$ of the total feed intake, respectively), however $G$. ulmifolia had the lowest consumption $(2.13 \%$ of the total feed intake). The same trend was observed when the data expressed as $\mathrm{g}$ DM per $\mathrm{kg}$ metabolic BW. Although a slight difference appears when the data are expressed as relative intake of every forage to the total forage intake, that the highest consumption ( $\mathrm{p}=0.001)$ was for $L$. leucocephala followed by $B$. alicastrum and $P$. oleracea then $M$. oleifera in the same significant level with $P$. oleracea, while G. ulmifolia was significantly the lowest forage consumed.

\section{Second trial}

Data presented in Table 4 shows significant $(\mathrm{p}=0.001)$ differences among all treatment groups. In general, rabbits fed $B$. alicastrum have the highest forage intake $(50.54 \%$ of the total feed intake) followed by such those fed $L$. leucocephala and P. oleracea $(45.91 \%$ and $42.44 \%$ of the total feed intake, respectively) then came $M$. oleifera in the same significant level with $P$. oleracea $(39.11 \%$ of the total

Table 3. DMI of the five forages when offered at the same time ( $\mathrm{n}=12$ rabbits for each mean)

\begin{tabular}{lccccccc}
\hline Forages & B. alicastrum & L. leucocephala & M. oleifera & P. oleracea & G. ulmifolia & SEM & p-value \\
\hline $\mathrm{g} \mathrm{DM} / \mathrm{d}$ & $6.30^{\mathrm{b}}$ & $20.44^{\mathrm{a}}$ & $5.44^{\mathrm{b}}$ & $5.78^{\mathrm{b}}$ & $1.7^{\mathrm{c}}$ & 0.41 & 0.001 \\
$\mathrm{~g} / \mathrm{kg}^{0.75} / \mathrm{d}$ & $5.11^{\mathrm{b}}$ & $16.57^{\mathrm{a}}$ & $4.42^{\mathrm{b}}$ & $4.68^{\mathrm{b}}$ & $1.38^{\mathrm{c}}$ & 0.34 & 0.001 \\
$\% \mathrm{DM} / \mathrm{d}$ & $16.32^{\mathrm{b}}$ & $49.95^{\mathrm{a}}$ & $14.37^{\mathrm{c}}$ & $15.14^{\mathrm{bc}}$ & $4.23^{\mathrm{d}}$ & 0.64 & 0.001 \\
\hline
\end{tabular}

$\overline{\mathrm{a}, \mathrm{b}, \mathrm{c}}$ Letters in the same row with different superscripts are significantly different $(\mathrm{p}<0.05)$.

Table 4. DMI of the five forages offered separately ( $\mathrm{n}=12$ rabbits for each mean)

\begin{tabular}{lccccccc}
\hline Forages & B. alicastrum & L. leucocephala & M. oleifera & P. oleracea & G. ulmifolia & SEM & p-value \\
\hline $\mathrm{g} \mathrm{DM} / \mathrm{d}$ & $40.87^{\mathrm{a}}$ & $33.95^{\mathrm{b}}$ & $25.69^{\mathrm{c}}$ & $29.49^{\mathrm{bc}}$ & $19.69^{\mathrm{d}}$ & 2.11 & 0.001 \\
$\mathrm{~g} / \mathrm{kg}^{0.75} / \mathrm{d}$ & $33.74^{\mathrm{a}}$ & $27.73^{\mathrm{b}}$ & $21.31^{\mathrm{c}}$ & $23.61^{\mathrm{bc}}$ & $16.79^{\mathrm{d}}$ & 1.77 & 0.001 \\
$\% \mathrm{DM} / \mathrm{d}$ & $27.27^{\mathrm{a}}$ & $22.71^{\mathrm{b}}$ & $17.13^{\mathrm{c}}$ & $19.74^{\mathrm{bc}}$ & $13.15^{\mathrm{d}}$ & 1.42 & 0.001 \\
\hline
\end{tabular}

${ }_{\mathrm{a}, \mathrm{b}, \mathrm{c}}$ Letters in the same row with different superscripts are significantly different $(\mathrm{p}<0.05)$. 
feed intake), while the lowest forage intake value was obtained with rabbits fed G. ulmifolia $(32.90 \%$ of the total feed intake). The same trend was obtained when the data expressed either as g DM per $\mathrm{kg}$ metabolic $\mathrm{BW}$ or as relative intake of every forage to the total forage intake.

Summarized in Table 5 the overall values of forage intake and the $\mathrm{CV}$ for both trials, show relatively higher $\mathrm{CV}$ values for the $1 \mathrm{st}$ trial than the 2 nd trial; ranged from $25.55 \%$ to $51.30 \%$ with an average of $34.28 \%$ for this trial, when compared with the CV values of the 2 nd trial which ranged from $15.34 \%$ to $17.26 \%$ with an average of $16.32 \%$.

\section{DISCUSSION}

It is worthy to note that chemical composition of forages may vary according to various factors such as climatic condition under which forage plants were grown, plant age as well as both soil type and fertility (Atawodi et al., 2008; Ayssiwede et al., 2010).

Results of chemical analysis of B. alicastrum and $G$. ulmifolia were nearly similar to findings of LizarragaSánchez (2000) being $41.8 \%$ and $32.4 \%$ for DM, $16.9 \%$ and $15.5 \%$ for $\mathrm{CP}, 28.8 \%$ and $25.9 \%$ for $\mathrm{ADF}, 11.6 \%$ and $10.9 \%$ for Ash, respectively. Also, results of chemical analysis of $L$. leucocephala and $M$. oleifera were globally similar to those of Abou-Elezz et al. (2011) being 23.61\% and $19.76 \%$ for $\mathrm{CP}, 40.38 \%$ and $44.42 \%$ for NDF, $25.69 \%$ and $27.11 \%$ for ADF, $8.27 \%$ and $9.61 \%$ for Ash, respectively. However, the value of CP for P. oleracea was observed to be lower than that published by Abaza et al. (2010) being 30.41\%, although it was nearly the same value for CF being $12.81 \%$ as found by the same authors. Values of condensed tannin for L. leucocephala, M. oleifera, and B. alicastrum are nearly similar to findings of Mutayoba et al. (2011) and Lizarraga-Sánchez (2000) being 2.35\%, 2.83\%, and 0.7\%, respectively although the value of G. ulmifolia was higher than that published by Lizarraga-Sánchez (2000) being $1.8 \%$.

Concerning the forage preference, it is observed that the results obtained from the two trials are almost similar where B. alicastrum and L. leucocephala were the forage plants

Table 5. Forage DMI (g/d) and CV\% for each trial ( $\mathrm{n}=12$ rabbits for each trial)

\begin{tabular}{lrlll}
\hline Forages & Trial 1 & $\mathrm{CV}(\%)$ & Trial 2 & $\mathrm{CV}(\%)$ \\
\hline B. alicastrum & $6.30^{\mathrm{b}}$ & 27.32 & $40.87^{\mathrm{a}}$ & 15.34 \\
L. leucocephala & $20.44^{\mathrm{a}}$ & 38.46 & $33.95^{\mathrm{b}}$ & 16.09 \\
M. oleifera & $5.44^{\mathrm{b}}$ & 28.77 & $25.69^{\mathrm{c}}$ & 17.26 \\
P. oleracea & $5.78^{\mathrm{b}}$ & 25.55 & $29.49^{\mathrm{bc}}$ & 16.24 \\
G. ulmifolia & $1.70^{\mathrm{c}}$ & 51.30 & $19.69^{\mathrm{d}}$ & 16.67 \\
Average & & 34.28 & & 16.32 \\
\hline
\end{tabular}

$\overline{\mathrm{a}, \mathrm{b}, \mathrm{c}}$ Letters in the same column with different superscripts are significantly different $(\mathrm{p}<0.05)$ most preferred by rabbits, and then $P$. oleracea and $M$. oleifera had a moderate preference level, meanwhile; $G$. ulmifolia was the least preferred one. In accordance with the present results, Nieves et al. (2004) found that diets containing $30 \%$ or $40 \%$ Leucaena leucocephala leaf meal were more palatable than diets containing the same levels of Arachis pintoi meal.

The high water content in P. oleracea and M. oleifera probably affected intake negatively. Arias et al. (2003) reported that the greatest disadvantage of foliages used as feeds is the low DM content, resulting in low DMI. The DM content can be improved by drying the foliages before feeding. On the other hand, the low preference of $G$. ulmifolia by rabbits was probably due to the high amount of anti-nutritional factors, such as condensed tannins in this plant $(6.5 \%)$, since the higher tannin content in a plant the less is its dry matter intake. The negative effects of tannins on intake and digestion are attributed to reduce palatability/intake, digestibility, nutrient availability, and weight gain (Silanikove et al., 1996; Rogosic et al., 2008). Tannins tend to decrease diet digestibility through their ability to bind with proteins and other materials, resulting in decreased diet intake (Chang et al., 1998; Al-Mamary et al., 2001). In this regard Mashamaite et al. (2009) reported that $4 \%$ is the acceptable level of tannins in rabbit feeds without negative effects on intake and digestibility.

The amounts of total protein intake were measured for both trials as g protein consumed of forage/s plus g protein consumed of concentrated feed/rabbit/d. The value of total protein intake for the 1st trial was relatively high (14.27 $\mathrm{g} /$ rabbit) compared to the amounts of total protein intake for the 2nd trial; that were 13.68, 12.55, 12.21, 11.90 and 10.27 $\mathrm{g} /$ rabbit for L. leucocephala, B. alicastrum, M. oleifera, $P$. oleracea, and G. ulmifolia, respectively. Current results of protein intake confirmed the findings of Thu and Dong (2008) who found that the total crude protein intake for growing rabbits fed on various levels of fresh Spophocarpus scandén with concentrated feed ranged from 10.9 to $15.0 \mathrm{~g} / \mathrm{d}$.

Regarding the total fiber intake ( $\mathrm{g}$ CF consumed of forage/s+g CF consumed of concentrated feed/rabbit/d), it was found that rabbits of the 1 st trial recorded slightly high value of total fiber intake which was 11.87 as compared to the total fiber intake of the 2nd trial which were 11.75 , 11.30, 9.69, 9.75, and 8.6 for B. alicastrum, L. leucocephala, M. oleifera, P. oleracea, and G. ulmifolia, respectively. These results of fiber intake were consistent of that reported by Supharoek et al. (2007) which was $11.5 \mathrm{~g} / \mathrm{d}$ for growing rabbits fed different forages together with concentrated feed.

In the 1st trial, the forage DMI varied much (5.44 to $20.44 \mathrm{~g} / \mathrm{d}$ ) as a result of this strategy, when all of the five forages were presented to the animals at the same time, consequently the consumption of one forage species will 
affect the quantity consumed of the other forages, since the capacity of the stomach is constant. While on the contrary that did not happen in the 2 nd trial, when just one forage was presented to every group of rabbits, due to the lack of forage competition on the gastrointestinal tract capacity. A similar result was observed by Dong and Thu (2012) who indicated that daily intake of forages was significantly higher and with low variance in a separate feeding method than in a mixed feeding method, the explanation was that the rabbits have high feed selection characteristics thus feeds offered separately stimulated them to consume more feed.

The recommendations deal with feeding/nutrition experiments in rabbits ranged the $\mathrm{CV}$ values for feed intake between $11 \%$ and $22 \%$ as reported by Fernández-Carmona et al. (2005). The CV value of the 2 nd trial (16.32\%) agreed with that finding, however the value of the 1 st trial (34.28\%) was observed to be higher than the range reported above, although the latter reflects the additive biological interactions among the forage plants consumed by rabbits in the course of this trial. This theory was reported by Ross and Max Shelton (1994) that some forage plants contain anti-nutritive factors which adversely affect nutritive value, but the combination between two or more plants could be inhibit the adverse effect of each others.

\section{CONCLUSION}

This study has shown that the findings of both trials were almost similar; however the method of presenting the forages separately to rabbits is methodologically more accurate than presenting them all together, although the latter is one of the more realistic methods to indicate voluntary feed preference. It can be also concluded that a range of tropical forages were eaten in acceptable quantities by rabbits, suggesting that diets based on such forages with a concentrate supplement could be used successfully for rabbit production. Nevertheless, this study was conducted over short period and longer-term studies, which examine growth performance as well, are needed before recommendations could be made on appropriate ration formulations for commercial use.

\section{ACKNOWLEDGEMENT}

This research work was partially funded by the scholarship awarded to the first author by the government of Mexico through the Ministry of Foreign Affairs (SRE).

\section{REFERENCES}

Abaza, I. M., M. A. Shehata, and A. M. Abbas. 2010. Nutritional and biological evaluation of portulaca oleracea (purslane) as untraditional protein source in feeding growing rabbits. Egyptian J. Nutr. Feed. 13:149-163.

Abou-Elezz, F. M. K., L. Sarmiento-Franco, R. Santos-Ricalde, and F. Solorio-Sanchez. 2011. Nutritional effects of dietary inclusion of Leucaena leucocephala and Moringa oleifera leaf meal on Rhode Island Red hens' performance. Cuban J. Agric. Sci. 45:163-169.

Al Mamary, M., A. Molham, A. Abdulwali, and A. Al-Obeide. 2001. In vivo effect of dietary sorghum tannins on rabbit digestive enzyme and mineral absorption. Nutr. Res. 21:13931401.

AOAC. 1995. Official methods of analysis. 16th Ed. Association of Official Analytical Chemists. Washington, DC.

Arias, L., J. Contreras, H. Losada, D. Grande, R. Soriano, J. Vieyra, J. Cortes, and J. Rivera. 2003. A note on the chemical composition and in vitro digestibility of common vegetables utilised in urban dairy systems of the east of Mexico City. Livest. Res. Rural Dev. 15(2). http://www.lrrd.cipav. org.co/lrrd15/2/aria152.htm Accessed January 21, 2014.

Asar, M. A., Mona Osman, H. M. Yakout, and A. Safoat. 2010. Utilization of corn-cob meal and faba bean straw in growing rabbits diets and their effects on performance, digestibility and economical efficiency. Egypt. Poult. Sci. 30:415-442.

Atawodi, S. E., D. Mari, J. C. Atawodi, and Y. Yahaya. 2008. Assessment of Leucaena leucocephala leaves as feed supplement in laying hens. Afr. J. Biotechnol. 7:317-321.

Ayssiwede, S. B., A. Dieng, C. Chrysostome, W. Ossebi, J. L. Hornick, and A. Missohou. 2010. Digestibility and metabolic utilization and nutritional value of Leucaena leucocephala (Lam.) leaves meal incorporated in the diets of indigenous seneghal chickens. Int. J. Poult. Sci. 9:767-776.

Chang, K. T., T. Y. Wong, C. L. Wei, Y. W. Huang, and Y. Lin. 1998. Tannins in human health: a review. Crit. Rev. Food Sci. Nutr. 38:421-464.

De Blas, J. C. and J. Wiseman. 2010. Nutrition of the rabbit. 2nd. CABI Publishing, Wallingford, UK. pp. 243-245.

Dong, T. K. N. and V. N. Thu. 2012. Effect of mixed or separate feedings and ration of Centrocema pubescens and Para grass on feed utilization, nutrient digestibility and growth performance of crossbred rabbits. In: Livestock-Based Farming Systems, Renewable Resources and the Environment (Ed. R. Preston and S. Southavong). Proceedings of the International Conference; 2012 June 6-9; Dalat, Vietnam.

Duncan, D. B. 1955. Multiple range and multiple test. Biometrics 11:1-42.

FAO. 1997. FAOSTAT Statistical Database.

Fernández-Carmona, J., E. Blas, J. J. Pascual, L. Maertens, T. Gidenne, G. Xiccato, and J. García. 2005. Recommendations and guidelines for applied nutrition experiments in rabbits. World Rabbit Sci. 13:209-228.

Lizarraga-Sánchez, H. L. 2000. Evaluación forrajera de cinco árboles nativos durante las lluvias en Yucatán. MSc. Thesis. FMVZ-University of Yucatán, México. p. 99.

Makkar, H. P. S., M. Blümmel, and K. Becker. 1995. Formation of complexes between polyvinily pyrorolidones or polyethylene glycols and their implication in gas production and true digestibility in vitro techniques. Br. J. Nutr. 73:897-913.

Mashamaite, L., J. W. Ng'ambi, D. Norris, L. R. Ndlovu, and C. A. 
Mbajiorgu. 2009. Relationship between tannin contents and short-term biological responses in male rabbits supplemented with leaves of different acacia tree species grown in Limpopo province of South Africa. Livest. Res. Rural Dev. 21(7). http://www.lrrd.cipav.org.co/lrrd21/7/mash21109.htm Accessed January 21, 2014.

McNitt, J. I., N. M. Patton, S. D. Lukefaht, and P. R. Cheeke. 1996. Rabbit Production, 7th Ed. Interstate Publishers in Company, Danville. pp. 144-278.

Mutayoba, S. K., E. Dierenfeld, V. A. Mercedes, Y. Frances, and C. D. Knight. 2011. Determination of chemical composition and anti-nutritive components for Tanzanian locally available poultry feed ingredients. Int. J. Poult. Sci. 10:350-357.

Nieves, D., S. Basilia, O. Teran, C. Gonzalez, and J. Ly. 2004. A note on the chemical composition and feeding characteristics of diets containing Leucaena leucocephala and Arachis pintoi for growing rabbits. Livest. Res. Rural Dev. 16(12). http://lrrd.cipav.org.co/ Irrd16/12/niev16099.htm Accessed January 21, 2014.

Raharjo, Y. C. and P. R. Cheeke. 1985. Palatability of tropical tree legume forage to rabbits. Nitrogen Fixing Tree Res. Rep. 3:3132.

Raharjo, Y. C., P. R. Cheeke, N. M. Patton, and K. Supriyati. 1986. Evaluation of tropical forage and by-product production. I. Nutrient digestibility and effect of heat treatment. J. Appl. Rabbit Res. 9:56-66.
Rogosic, J., R. E. Estell, S. Ivankovic, J. Kezic, and J. Razov. 2008 Potential mechanisms to increase shrub intake and performance of small ruminants in mediterranean shrubby ecosystems. Small Rumin. Res. 74:1-15.

Ross, C. Gutteridge and H. Max Shelton. 1994. Forage Tree Legumes in Tropical Agriculture. pp. 177-185.

Silanikove, N., N. Gilboa, A. Perevolotsky, and Z. Nitsan. 1996. Goats fed tannin-containing leaves do not exhibit toxic syndromes. Small Rumin. Res. 21:195-201.

Somers, N., B. D'Haese, B. Bossuyt, L. Lens, and M. Hoffmann. 2008. Food quality affects diet preference of rabbits: experimental evidence. Belg. J. Zool. 138:170-176.

Supharoek, N., M. Choke, and L. Inger. 2007. Effect of different forages on feed intake, digestibility and growth performance of rabbits. In: Matching Livestock Systems with Available Resources (Ed. Reg Preston and Brian Ogle). Proceedings MEKARN Regional Conference 2007; 2007 November 25-58; Halong Bay, Vietnam.

Thu, V. N. and T. K. N. Dong. 2008. A study of associated fresh forages for feeding growing crossbred rabbits the Mekong delta of Vietnam. In: Organic rabbit production from forages (Ed. Reg Preston and Nnguyen Van Thu). Proceedings MEKARN Rabbit Conference; 2008 November 25-27; Cantho University, Vietnam.

Van Soest, P. J., J. B. Robertson, and B. A. Lewis. 1991. Methods for dietary fiber, neutral detergent fiber and nonstartch polysaccharides in relation to animal nutrition. J. Dairy Sci. 74:3583-3597. 